UDC 81'42'44: [811.111+811.161.2]

DOI https://doi.org/10.32841/2409-1154.2021.50-1.7

\author{
Borysov O. O., \\ Doctor of Sciences (Linguistics), Associate Professor, \\ Head of the Germanic Philology Department \\ T. H. Shevchenko National University "Chernihiv Colehium"
}

\author{
Vasylieva O. H., \\ Doctor of Philosophy (Linguistics), \\ Associate Professor of the Germanic Philology Department, \\ T. H. Shevchenko National University "Chernihiv Colehium"
}

\title{
SYNTACTIC STYLISTIC MEANS OF THE BRITISH AND UKRAINIAN PARLIAMENTARY DEBATE
}

Summary. The article is devoted to highlighting the problem of different syntactic stylistic means realization in the speech of politicians that debate in the British and Ukrainian parliaments. In this paper the essence of debate as a specific and very important communicative event for the political life of both countries has been presented. In the course of the research the structure of this political activity has been outlined, the type and the format of the dialogical interaction have been established, and the place of its rhetorical discourse within the boundaries of political discourse has been substantiated. For the further all-embracing understanding of the specificity of the national debate in the parliaments of Great Britain and Ukraine, we found it necessary to analyze and compare the definitions of the key lexical units that designate the social phenomenon, taken from the present-day English and Ukrainian explanatory lexicographical sources. As a result, isomorphic and allomorphic features of prototypical understanding of such social interaction in the communicative spaces of both ethnic communities have been established. Among many other sets of units that can produce a successful communicative impact on direct or distant hearers, who represent a potential electorate and participate in these political discussions due to the mass media, the syntactic stylistics is undoubtedly viewed by the speakers (and, consequently, by linguists) as an indispensable and powerful means of debate rhetoric. Various views of scientists of native and foreign linguistics on the issue of syntactic stylistic units differentiation have also been presented in the article. Through the prism of one of the classifications the speeches of debaters in the British and Ukrainian parliaments have been analyzed and isomorphic as well as allomorphic features of syntactic stylistics have been established. The authors of the paper have found out both qualitative and quantitative differences in the usage of the syntactic expressive means and stylistic devices by the British and Ukrainian politicians.

Key words: political debate, political discourse, stylistics, syntactic stylistics, expressive means, stylistic devices.

Inroduction. Political discourse realized in its various genres is undoubtedly in the focus of today's linguistic interests $[1 ; 2 ; 3 ; 4]$. As one of the types of rhetorical discourse, it is distinguished by its own specificity predetermined by the orator's motives and realized in the peculiar compositional, lexico-semantic and syntax-stylistic characteristics [5, p. 1568]. Taking into consideration the fact that political communication has always been in the focus of public and linguistic attention, the contrastive study of speech peculiarities of politicians participating in debates in British and Ukrainian parliaments is a highly topical issue at the moment. This paper tackles the issue of syntactic expressive means and stylistic devices employed by the members of the House of Commons (HOC) of the UK Parliament and politicians of the Verkhovna Rada (VR) of Ukraine. So far it has not been an object of close attention from the contrastive perspective though stylistic peculiarities of speech of political debate were highlighted in a number of works $[6 ; 7 ; 8$, etc. $]$

The aim set presupposes the accomplishment of the following objectives: 1) to define the genre of "parliamentary political debate"; 2) to consider isomorphic and allomorphic features of ethnic understandings of debate presented in their lexicographical definitions in present-day English and Ukrainian; 3) to give a survey of the existing classifications of syntactic stylistic units and produce our view on the typology of these elements; 4) to single out isomorphic and allomorphic features of political argument in the British and Ukrainian parliaments in the framework of syntactic stylistics. The material analyzed represents debates on political and economic issues downloaded from the Internet resources (2951 syntactic units: Eng. 1362; Ukr. 1589) limited by the year of 2014.

Results and discussion. Political debate presents a form of parliamentary activity the core of which is built around a discussion of some problem brought forward for consideration $[1 ; 4 ; 9]$. In fact, the debate is an argument between political subjects concerned with the approval of a legislative draft. This discourse subgenre is a result of a collision of several views on the existing problem and it allegedly outlines effective ways of its solving. The essence of this dialogical interaction typically covered by mass media is that deputies try to convince others of the soundness of their party's ideas and, thus, to gain a potential voters support [1, p. $352-357 ; 2$, p. $395 ; 3$, p. $263 ; 4$, p. $37-38 ; 10$, p. 89 ; 11, p. 85-90]. It is obvious that the debate discourse constitutes a complex communicative event that includes a report of the draft presenter, the following reactions of the members of the parliament given in statements and questions, the accompanying comments of the speaker, unregulated deputies' communicative interventions, the process of voting, etc. This type of a dialogical interaction is an institutional one. It is determined by the specific chronotope, parliamentary procedure, various regulations and standards, including constitutional ones. That is why a high level of formality of such communication realized in the official style of speech with 
terminological abundance and stylistic severity turns out to be a typical feature of parliamentary debate sessions.

The present-day English and Ukrainian explanatory dictionaries basically reveal a similar understanding of debate in British and Ukrainian ethnic communities. The meanings of the corresponding lexemes in English and Ukrainian possess the same semantic components ('discussion' / 'обговорення' and 'particularmatter', 'subject' / 'яке-небудьпитання'), cf. debatea formal discussion on a particular matter in a public meeting or legislative assembly, in which opposing arguments are put forward and which usually ends with a vote [12], serious discussion of a subject in which many people take part [13] and дебати обговорення якого-небудь питання, обмін думками; суперечки, duckycii $[14 ; 15]$. These archesemes 'discussion' / 'обговорення' (якого-небудь питання) / 'обмін думками' basically coincide. But in English the component 'discussion' is further specified by the information which incorporates the aim of talking - "in order to reach a decision' (discussion is the action or process of talking about something in order to reach a decision or to exchange ideas [12]) absent in Ukrainian. At the same time lexeme дебати represents information about the characteristics of such talking 'широке', 'публічне' which concerns a disputable issue - 'спірне' ('питання') (дискусія - широке публічне обговорення якогонебудь спірного питання [15]. The differential semes 'public' and 'публічне' are isomorphic for both meanings. The semes 'many people' and 'иироке' also turn out to reflect the same ideas.

The part of the meaning of дебати - суперечки (словесне змагання між двома або кількома особами, при якому кожна із сторін обстоює свою думку, правоту [14]) - additionally expresses the idea of the contest between speakers. Here the common knowledge about the existence of different views ('opposing arguments'/ 'своя думка') of the parties involved in talking is revealed. Further analysis of the meanings demonstrates the fact of a more elaborated interpretation of the debate by the British community as it also encompasses the phase moments of the event procedure ('arguments are put forward', 'ends with a vote'), its official character ('formal', 'legislative') and social localization ('a (public) meeting', '(legislative) assembly').

To sum it up, the archesemes 'discussion' / 'обговорення' manifest the same denotatum in both ethnic communities. The other isomorphic features are those differential components that introduce the problem of this kind of talking - '(particular) matter', 'subject' / 'яке-небудь питання'. The semes '(opposing) arguments'/ '(своя) думка', 'public'/ 'публічне', '(many) people' and 'широке' also make the English and Ukrainian meanings close. The crucial difference, however, except the presence of the semes reflecting the phasal character of the debate procedure, its official character and social localization, is English understanding of the fact that such talking must end with some decision taken - 'to reach a decision'. In other words, it underlines a logical and pragmatic approach to such type of communication.

To produce a necessary communicative impact (the approval of their party's legislative acts or undermining the ones of their ideological opponents), the spokespersons must not only make arguments "for" and "against" but employ a whole inventory of the most effective language and speech means to express their ideas. Expressive and emotionally coloured speech units serve not only as a means of underlining one's logical argumentation. They can also easily cloud the issue of the strong opponent's argument, underplay the reasonableness of the draft, and interfere with mass addressee's evaluation of its effectiveness or ineffectiveness in some sphere of society activity. In this way syntax stylistics tends to be a powerful rhetorical instrument both of direct control and manipulation of public opinion.

As for the issue of a stylistic potential of language differentiation, V. Zhukovska rightfully states that there exist quite a number of terms to denote those particular expressive, emotive and evaluative means with which utterances are filled. They make sentences more effective rendering additional information into the interactional space of interlocutors. They are alternatively called expressive means, stylistic means, stylistics devices, tropes, figures of speech, etc. [16, p. 18]. Generally, there exists the unanimity of approaches to the expressive potential of the language though the criteria of its differentiation can vary in the works on stylistics.

I. Galperin, one of the most prominent scholars in the field of stylistics, divides all stylistic tools of language into expressive means (EMs) and stylistic devices (SDs). The EMs are phonetic, morphological, lexical, phraseological and syntactic forms which exist in the given language as a system for the purpose of a logical and/or emotional intensification of the utterance [17, p. 27]. The stylistic device (SD) is a conscious and intentional intensification of some typical structural and /or semantic property of the language unit promoted to a generalized status and thus becoming a generative model. The SD is an abstract pattern, a mould into which any content can be poured [17, p. 30].

Analyzing the definition of the SD by I. Galperin, the other wellknown philologist I. Arnold claims that the criterion of intention can not lie in the basis of EMs and SD differentiation. She stresses that EMs don't create images but intensify speech expressiveness and emotiveness with the help of special constructions: inversions, rhetorical questions, parallel constructions, antithesis, etc. She suggests using the term "SD" conventionally in regard to the typical character of this or that poetic construction [18]. Within the SD, the scholar differentiates the phonetic means of sound organization of speech (alliteration, onomatopoeia, etc.), tropes (peculiar of words used in transferred meaning), and syntactic or stylistic figures (peculiar of syntactic structures) [18]. The latter are similarly defined by the famous Ukrainian linguist A. Koval as phenomena of stylistic syntax which combine such features of syntactic constructions as their lexical and intonation peculiarities [19, p. 301].

M. Brandes claims that the expressive potential of language is a stable and meaningful system of EMs that possess invariant meanings. As a result of the creative processing of information provided by the expressive language potential, new SDs emerge in the language system. They appear due to purposeful violation of the existing sentence or text unit distribution [20, p. 297-300]. Stylistic elementary forms, which are the means of no connotative value that gain their expressiveness in the utterance are also distinguished [20, p. 298]. In its turn, the scholars O. Morokhovsky, O. Vorobjova, N. Lyhosherst and Z. Tymoshenko define an EMs as a marked member of stylistic or functional-stylistic opposition (that renders expressiveness) with invariant semantics in language. A SD emerges in context due to syntagmatic relations born between speech units of the same or different levels [21, p. 43-44]. Prof. Yu. Skrebnev produces a unique approach to the stylistic means differentiation distinguishing paradigmatic and syntagmatic stylistics on the phonetic, lexical, syntactic and semantical levels of language [22, p. 32]. The paradigmatic syntax presupposes 
the word order, completeness of sentence structure, communicative types of sentences, types of syntactic connection [22, p. 77-97]. Syntagmatic syntax includes parallel construction, anaphora, epiphora, anadiplosis, chiasmus [22, p. 139-143].

It is needless to say that there are various viewpoints on the problem of stylistic syntax differentiation in contemporary philological literature. To classify the syntax means I. Galperin uses the following criteria: 1) particular ways of combining parts of the utterance (stylistic inversion, detached constructions, parallel constructions, repetitions, enumeration, antithesis, etc.); 2) compositional patterns of syntactic arrangement (asyndeton, polysyndeton); 3) a particular use of colloquial constructions (ellipsis, aposiopesis, indirect speech, etc.), 4) a stylistic use of structural meaning (rhetorical questions, litote) [17, p. 180-228]. In a similar way, I. Arnold singles out stylistic units on the basis of such criteria: 1) an unusual arrangement of elements (inversion), 2) a transposition of syntactic structures (rhetorical questions), 3) an introduction of new elements without contents extension (a repetition), 4) an omission of logically necessary elements (ellipsis, aposiopesis), 5) a sentence closeness violation (anacoluthon, parenthetic constructions) [18]. Prof. V. Kukharenko also uses the term a syntactic stylistic device. Its effect depends on the following factors. Firstly, it is the arrangement of sentence members, namely repetition (anaphora, epiphora, framing), parallel constructions, chiasmus, inversion, suspense, detachment) [23, p. 78-83]. Secondly, the completeness of a sentence structure presupposes the functioning of ellipsis, one-member sentence, apokoinu constructions, aposiopesis [23, p. 85-86]. Finally, the criteria necessarily involve various types of connections used within the sentence or between sentences. So a repeated use of conjunctions is called polysyndeton and their deliberate omission is asyndeton [23, p. 89].

A. Kovalj considers repetitions, antithesis, inversion, rhetorical questions, asyndeton, polysyndeton, elliptical constructions, breakin-the-narration to be stylistic figures [19, p. 301]. Such units as homogeneous parts of the sentence, detached constructions, indirect speech and some other elements are referred by the scientist to the rubric of syntactic stylistic categories [19, p. 221-301].

In the conception of M. Brandes all syntactic SDs are grouped into syntactic EMs (the length of the sentence, its semantic type, etc.) and SDs proper. According to a number of principles the following SDs are singled out: 1) ellipsis, aposiopesis, nominal sentences (sentence model reduction) (on the basis of a structure change), 2) enumeration, emphatic constructions, various repetitions (a sentence model expansion), 3) sentence structure transformation (periods), 4) the violation of word-order (anacoluthon, parenthesis, etc.); 5) rhetorical questions (sentence types transposition); 6 ) inversion (on the basis of the word-order change in the sentence) [20, p. 305-326]. In their turn, L. Jefimov and O. Jasinecjka define EMs of language as those phonetic, morphological, lexical, syntactical units and forms which make speech emphatic [24, p. 11]. Syntactic EMs are, for example, emphatic constructions, stylistic inversion. SDs (tropes, figures of speech) are speech phenomena that don't exist out of the given context. According to the principles of their formation, SDs are grouped into phonetic, lexicosemantic and syntactic types [24, p. 12]. The latter are divided on the grounds of a sentence model extension (repetition, enumeration, polysyndeton), sentence model reduction (ellipsis, aposiopesis, asyndeton, nominal sentences), and disruption of syntactic models (parceling) [24, p. 73-85].
In this paper we use the classification presented in the work “Стилистика английского языка" under O. Morohovsky guidance [21, p. 133-134]. It partly correlates with the classifications mentioned above but seems to be more elaborated and produces the most transparent criteria for the EM and SD differentiation, thus being more acceptable for our investigation. Thus, we divided the stylistic potential of language into EMs and SDs.

The research conducted revealed similar and different features of the national debates. The isomorphic features of political debate speech are the following ones. Firstly, in both parliaments the deputies tend to actively employ such expressive means as elliptical constructions; homogeneous parts of the sentence (enumeration), emphatic constructions, repetition (the expansion of the initial model); stylistic inversion (the change of the order of the initial model components). Secondly, stylistic devices are also actively used, namely rhetorical questions (the transposition of syntactic structures meanings in the context); parallel constructions, anaphora, epiphora, chiasmus united in this article under the title "stylistic repetition" (the interplay of syntactic structures in the context); parceling (the transposition of the meaning of the way of connection) [21]. The difference lies in the fact of various intensity of the usage of this or that stylistic unit.

The analyzed material revealed either the absence of the other elements of stylistic syntax (in such a case we consider them to be potential - those that can be found out under the condition of the samples expansion) or several examples only because of their not being popular with the politicians, thus they didn't get the statistic expression. It goes about detached constructions, asyndeton, parceling, polysyndeton, aposiopesis, etc. For instance, British politicians don't turn to ellipsis while making their speeches. The only examples found contain the elliptical cliché construction "thank you": e.g. N. Evans: Thank you, Mr Speaker. I will ask my honourable Friend's question for him [25]. As A. Kovalj states, the ellipsis makes the utterance dynamic and expressive, thus creating the intonation of a live, agitated oral speech used in everyday situations [19, p. 13, p. 189]. It is clear that such a type of speech is not a priori for the reserved, argumentative and unemotional character of institutional interaction moulded in the form of the political debate.

So, the analyzed British debates (with $24,9 \%$ of stylistic units of the total number of sentences) are characterized by a more intensive usage of such expressive means, as

1) enumeration (29,9\%, cf. Engl. 43,4\% / Ukr. 14,7\%): e.g. T.May: Communications data the "who, where, when and how" ... are crucial to fighting crime, protecting children, and combating terrorism! [26] and Яценюк А.П.: ...законопроект про відновлення дії Конституиії повинен був бути проголосований. підписаний і оприлюднений... [27];

2) lexical repetition (10,9\%, cf. Engl. 34,4\% / Ukr. 27,8\%): e.g. A. Cunningham: Carbon taxes have been imposed by consecutive Governments for a very-very good reason [28]; J. Bercow: Order! Order! The Ayes to the right is four hundred fortynine and the Nos to the left thirty-three [26] and Турчинов O.В.: ...ми свідомо робили те, що робили, розуміючи необхідність і відповідальність... [27], Шуфрич Н.І.: У мене прохання, щире прохання, або утриматись від голосування до завтра, або проголосувати з формулювання [27];

3) emphatic constructions (11,7\%, cf. Engl. 4,9\% / Ukr. 1,2\%): e.g. J. Walley: I congratulate my honourable Friend on securing 
this debate. Does he agree that we do face the huge energy security and energy affordability issues? [28]; A. Lansley: It is the leader party who has cut the budgets by eight percent! [25] and Шуфрич H.I.: Невже у вас нема терпимості і відповідальності?! Чи ви чекаєте, хто де буде і яку посаду як потім ділити?! [29]; Ляшко О.В.: I нехай відповідають і не ховаються! [30].

In its turn, the Ukrainian debates (with $30,6 \%$ of stylistic units of the total number of sentences) are marked by the usage of the following stylistic units, as

1) elliptical sentences (12,8\%) (Ukr. 25,5\%): e.g. Ващук К.T.: Звертаюся від імені всіх благодійних організацій Волинської області [30]; Турчинов О.В.: Можемо ставити наголосування? Можемо. [30];

2) inversion (14,2\%, cf. Engl. 1,7\% / Ukr. 8,9\%): e.g. A. Hammond: Many now have no home to return to [31] and Головуючий: Зразковими обов'язково ми будемо [30];

3) stylistic repetition of different types (12,4\%, cf. Engl. 8,1\% / Ukr. 12,8\%): e.g. T. May: They can prove or disprove alibis. They can identify links between potential criminals. They can tie suspects and victims to a crime scene [26]; D. Burrowes: But have we not reached the threshold at which there is evidence of both a direct national threat and human catastrophe. The Prime Minister said that if there was further evidence of a direct national threat and human catastrophe that would warrant further military action

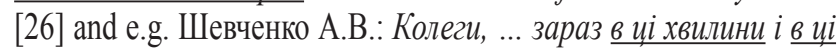
дні країна чекає дуже мудрих і виважених рімень [32]; Гриценко А.С.: Якщо нам треба взяти час, якщо треба роздрукувати документи, проєкти і для иього треба перерву годину, давайте візьмемо годину і попраџюсмо більме [30];

4) rhetorical questions (8,1\%, cf. Engl. 7,5\% / Ukr. 9,1\%): e.g. Ch. Bryant: Both today and last week, the Home Secretary has drawn a distinction between the data and the content. May I suggest to her that reliance on that distinction may not be legally valid in the future? [33]; A. Eagle: That is an arcane and opaque process that does little to scrutinise the actual spending of the Government. Does the Leader of the House agree that we need to reform the estimates process to ensure real scrutiny? [26] and Лабунська А.В.: Taк вid чого ви відрізняєтесь від інших, які були? Ви нікого не чуєте! Що ви робите? [34]; Ткачук Г.В.: Я не буду перераховувати всіх тих людей, а ви їх знаєте ие: Пашинський, Сенченко і багато інших, які сьогодні чомусь праиюють на двох посадах ... Дайте, будь ласка, відповідь, коли че беззаконня закінчиться? [32];

Here it is worthwhile mentioning that an isomorphic feature of the debate lies in the fact of aposiopesis absence in the speech of politicians of both parliaments. This SD also emerges when a person is agitated or the addresser wants the addressee to guess what is meant in this or that utterance [19, p. 188]. The deputies are well aware of the fact that, firstly, to be understood clearly by the other politicians and their voters they must finish their thoughts; secondly, the sentences with the break-in-the-narration can contextually produce the impression of some addresser's confusion thus creating an unfavourable impression of one's speaking. This refers to parceling as well.

Conclusion. Thus, the isomorphic features of the compared British and Ukrainian parliamentary debates are, on the one hand, the usage of enumeration, emphatic constructions, repetition, inversion that we treat as expressive means and a number of stylistic devices, namely rhetorical questions, stylistic repetitions, and, on the other, the absence, for example, of such stylistic elements as aposiopesis and parceling. Furthermore, there are qualitative and quantitative differences in the usage of the expressive means and stylistic devices. The crucial difference is, first of all, that Ukrainian discourse is more emotionally coloured from the standpoint of stylistic syntax. Secondly, it is curious enough that ellipsis is actually absent in the analyzed British political discourse. The other differences are that the British debate is characterized by a more intensive usage of enumeration, repetition, emphatic constructions whereas the Ukrainian debate is marked by the usage of elliptical sentences, inversion, stylistic repetition and rhetorical questions.

The prospect for further research is the study of the tropes as lexico-stylistic devices of debaters' speech in the British and Ukrainian parliaments.

\section{References:}

1. Dijk van T. Text and Context of Parliamentary Debates. Cross-Cultural Perspectives on Parliamentary Discourse / Ed. P. Baley. Amsterdam : Benjamins, 2004. P. 339-372.

2. Glazer J., Rubinstein A. A. Game Theoretic Approach to the Pragmatics of Debate: An Expository Note. Game Theory and Pragmatics. 2006. P. 251-265.

3. Славова Л.Л. Мовна особистість лідера у дзеркалі політичної лінгвоперсонології: США-Україна. Житомир : Вид-во ЖДУ, $2012.360 \mathrm{c}$.

4. Vukovic M. Strong Epistemic Modality in Parliamentary discourse. Open Linguistics. 2014. Vol. 1. Iss. 1. P. 37-52.

5. Спиридовский О.В. Парламентские дебаты как жанр политического дискурса. Научный альманах. 2015.9 (11). С. 1568-1574.

6. Карпусенко М. В., Карпусенко Н. В. Стилістичні особливості синтаксичних структур президентських дебатів (на прикладі третіх дебатів Х. Клінтон та Д. Трампа). Науковий вісник Міжнародного гуманітарного університету. Сер.: Філологія. 2018. № 33. T. 2. С. 48-50.

7. П'єцух О. Оцінний компонент політичного дискурсу парламентських дебатів у Сполученому королівстві. «Південний архів» (філологічні науки). 2017. № 68. С. 118-120.

8. Стецик Т.С. Лінгвопрагматика стратегії персуазивності в дебатах і промовах сучасних американських політиків : автореф. дис. ... канд. філол. наук : 10.02.04. Чернівці, 2016. 22 с.

9. Грушанська Н. Політичні дебати. Юридична енциклопедія / за ред. Ю. Шемшученко. К. : “Укр. енцикл.”, 1998. URL : http:// cyclop.com.ua/content/view/1236/58/1/21/ (Accessed 14.12.2020).

10. Сайтарли I. А. Культура міжособистісних стосунків. Київ : Академвидав, 2007. $240 \mathrm{c}$.

11. Emerson P. Debates and Decisions. Journal of Dialogue Studies. 2013. Vol. 1. № 3. P. 81-95.

12. Oxford Living Dictionaries Online. URL: https://en.oxforddictionaries. com/ (Accessed 25.12.2020).

13. Cambridge Dictionary Online. URL : http://dictionary.cambridge.org/ dictionary (Accessed 25.12.2020).

14. “Словник української мови” в 11 томах. Київ : Наукова думка, 1970-1980. URL : http://sum.in.ua (Accessed 25.12.2020).

15. Словник української мови online, томи 1-8. URL : http://services. ulif.org.ua/expl/Entry/index?wordid=21220\&page $=71$ (Accessed 25.12.2020).

16. Zhukovska V.V. English Stylistics: Fundamentals of Theory and Practice. Житомир : Вид-во ЖДУ ім. І. Франка, 2010. 240 с.

17. Galperin I.R. Stylistics. M. : Higher School, 1977. 331 p.

18. Арнольд И.В. Стилистика. Современный английский язык. М.: Флинта.: Наука, 2002. 384 с.

19. Коваль А.П. Практична стилістика сучасної української мови. Київ : Вища школа, 1987. 347 с. 
20. Брандес М.П. Стилистика текста. Теоретический курс. М. : Прогресс-Традиция; ИНФРА-М, 2004. 416 с.

21. Мороховский А.Н., Воробьева О.П., Лихошерст Н.И., Тимошенко З.В. Стилистика английского языка. Киев : Вища школа, 1984. 248 с.

22. Скребнев Ю.М. Основы стилистики английского языка. М. : ООО “Изд-во Астрель": ООО “Изд-во АСТ”, 2003. 221 с.

23. Kukharenko V.A. A Book of Practice in Stylistics. Вінниця : Нова Книга, 2003. 160 c.

24. Єфімов Л.П., Ясінецька О.А. Стилістика англійської мови і дискурсивний аналіз. Вінниця : Нова Книга, 2004. 240 c.

25. House of Commons, 3 July 2014. Democracy Live : site. URL : http://www.bbc.co.uk/democracylive/house-of-commons-28142683.

26. House of Commons, 15 July 2014 (1). Democracy Live : site. URL : http://www.bbc.co.uk/democracylive/house-of-commons-28311912.

27. Верховна Рада. 22.02.2014. Yоитиве : сайт. URL http:// www.youtube.com/watch?v=5d3Hj8YpXSU.

28. House of Commons, 11 September 2014. Democracy Live : site. URL: http://www.bbc.co.uk/democracylive/house-of-commons-29156010.

29. Верховна Рада. 13.05.14. Үоитиве : сайт. URL http:// www.youtube.com/watch?v=B9fuiD19kj8.

30. Верховна Рада. 25.02.14. YouTube : сайт. URL : http:// www.youtube.com/watch?v=6Gb03 CIBglg.

31. House of Commons, 10 September 2014. Democracy Live : site. URL : http://www.bbc.co.uk/democracylive/house-of-commons-29135286.

32. Верховна Рада. 18.04.14. ҮouTube : сайт. URL : http:// www.youtube. $\mathrm{com} /$ watch? $\mathrm{v}=$ OQte_RTmLvs.

33. House of Commons, 15 July 2014 (2). Democracy Live : site. URL : http://www.bbc.co.uk/democracylive/house-of-commons-28320473.

34. Верховна Рада. 23.02.2014. ҮоиТиве : сайт. URL : http:// www.youtube.com/watch?v=hSF_DZUhcMc.

Борисов О., Васильєва О. Засоби стилістичного синтаксису в британських та українських парламентських дебатах

Анотація. Стаття присвячена висвітленню проблеми реалізації різноманітних засобів стилістичного синтаксису в мовленні політичних діячів, які беруть участь у британ- ських та українських парламентських дебатах. У розвідці визначається сутність дебатів як специфічної та вельми значущої для політичного життя обох країн комунікативної події. У процесі дослідження було окреслено універсальну структуру перебігу цієї парламентської активності, обгрунтовано тип та формат проведення такої діалогічної взаємодіï, а також було визначено місце риторичного дискурсу дебатів у межах політичного дискурсу. Для подальшого поглибленого розуміння специфіки перебігу національних дебатів у парламентах Великобританії та України за допомогою аналізу словникових дефініцій одиниць їхньої номінації, вилучених із тлумачних лексикографічних джерел сучасної англійської та української мов, компонентного та контрастивного аналізу було встановлено ізоморфні та аломорфні риси стереотипного розуміння такого типу соціальної інтеракції в комунікативних просторах обох етносів. Серед низки багатьох інших одиниць здійснення успішного комунікативного впливу на безпосередніх або віддалених співрозмовників, які є потенційним електоратом тієї чи іншої політичної партії та беруть участь у такій комунікації завдяки засобам масової інформації, стилістичний синтаксис, безумовно, розглядається мовцями (та, у свою чергу, лінгвістами) як невід'ємний та потужний засіб риторики під час парламентських дискусій. У роботі було також представлено та розглянуто різні погляди на проблему диференціації стилістичних одиниць синтаксису у вітчизняній та закордонній лінгвістичній науці. Згідно 3 одним із вибраних підходів аналізується мовлення дебатантів у британському та українському парламентах 3 подальшим встановленням ізоморфних та аломорфних рис вживаного ними стилістичного синтаксису. При цьому авторами статті виявлені як якісні, так і кількісні відмінності у вживанні британськими та українськими політиками тих чи інших експресивних засобів та стилістичних прийомів синтаксису.

Ключові слова: політичні дебати, політичний дискурс, стилістика, стилістичний синтаксис, виразні засоби, стилістичні прийоми. 